\title{
Young Investor's Instagram Usage Behavior and Investment Risk Appetite
}

\author{
Gesti Memarista1', Angela Merici Adinda Puspita ${ }^{2}$ \\ 1 Universitas Katolik Widya Mandala, Surabaya, Indonesia \\ gestimema@gmail.com \\ 2Blesscon \\ anngela.putri 2796@gmail.com \\ ${ }^{\bowtie}$ Corresponding Author: gestimema@gmail.com
}

\begin{abstract}
Online Social Network Sites (SNSs) provide a lot of information to understanding young investor behavior. As the interest of financial practitioners, the young investor has their risk tolerance. So, this study aims to predict the investment risk appetite through social networking sites (SNSs) as a vast information exchange platform using young investors' Instagram usage behavior. This research uses investment risk appetite and extroversion personality as the dependent variables. Moreover, the number of Instagram followers, spending time on Instagram, the frequency of Instagram users to log on, Instagram usage for personal expression, and Instagram usage for social relationships as the independent variables. The researchers use 300 young stock investors through the online questionnaire. The results study show that the number of followers on Instagram and the Instagram usage for social relation significantly affect extroversion personality. The extroversion personality significantly affects the investment risk appetite. Otherwise, spending time on Instagram, frequency of log on to Instagram, the use of Instagram for self-expression do not considerably affect the extroverted personality. This result obtains the probability of understanding the young investor's risk appetite through their Instagram usage behavior. Thus the financial consultant can gather the information to understand their current social network activities.
\end{abstract}

Keywords: Instagram usage behavior; investment risk appetite; extroversion personality; social networking sites (SNSs)

\section{Introduction}

Investment is one of the primary decisions in managing the finances of young investors. It is the financial planning to the young person, significantly increase the financial ability in the future (Brahmana \& Memarista, 2017). To support the investment decision, the young investor must tolerate their investment risk appetite in financial assets. The investment risk appetite tends to affect their investment choice in the stock market. The young investors desire to carry on the investment risk, bound with their subjective behavior factors. The appetite for investment risk by the young investor is a vigorous nature of financial behavior that varies throughout their ages. Consequently, their financial consultant must understand among chances enduring the tendencies of unique investors at their financial planning horizons. Mainly, these young investors in university students are the millennial generation who have compromised with the digitalization era with their dynamic FOMO (Fear of Missing Out) behavior.

Today, the digitalization era will deal with a common language used to describe gadgets to young investors. For example, smartphones, computers, electronic mail, the internet, and many more. This information resulting from those things is grouped, saved, changed, and processed in numbers form. Digital cannot be separated from technology. It is a scientific method to reach the practical goal of applied science and provide things that need continuity and comfort the stock market investors' lives. As time grows, digital and technology collaborate with the internet to reach investment information and financial knowledge.

According to Kemp (2020), internet users, social media users, and mobile connections are growing every year in Indonesia. Indonesia's internet users in January 2020 were 175,4 million. It was increased by 25 million or produced $17 \%$ between 2019 and 2020. Furthermore, there was an 8,1\% increasing in social media users in January 2020 since April 2019 in Indonesia. It was 160 million people or increased around 12 million. At the same time, the mobile connections were 338,2 million in January 2020 in Indonesia, which increased by 15 million or grown 4,6\% from January 2019 until January 2020. This number was approximate to $124 \%$ of Indonesia's population. So that, it indicates that a lot of Indonesian people do online activities related to social networking. Especially young people will dominate the use of social networking media, such as Instagram.

Online Social Network (OSN) is an active information resource used to determine the young stock investor behavior and their appetite for investment risk in Indonesia. Many users and the information barter between colleagues, capital market authority firm, and security companies support explaining their attitude and behavior. Not only for a particular time but also done periodically according to the personal financial consultant that needs to explore investor behavior and the stock information (Wasiuzzaman \& Edalat, 2016). Psychologically, OSN users are communicating their real personality effectively through Social Networking Sites (SNSs). Thus, it encourages the young stock investors' interpersonal perception accurately. Specifically, from 5 personality traits, the accuracy of the extroversion level's prediction is the strongest. For example, as Instagram is the most favorite SNSs activity for young investors, it can be further analyzed as Instagram usage behavior. Furthermore, the personality type of an individual investor can be measured and understood very well. 
SNSs activity through Instagram can be analyzed with several factors. Wasiuzzaman and Edalat (2016) stated that the number of followers, time spend on Instagram, frequency of logging in to Instagram, self-expression, and social connection through Instagram are considered to measured Instagram SNSs activity. Those measurements will show the different backgrounds that make the Instagram users have a unique extroversion personality type and dynamic characteristic for facing the investment risk. According to Filbeck et al. (2005), there is a relation between the dimension of personality type and risk aversion. It shows that extroversion significantly affects risk tolerance.

Our first purpose is to investigate the possible determinant of the investment risk appetite by extroversion through Instagram usage behavior. Somebody with an extrovert personality tends to open new things without considering the risk of having lower risk aversion. Every SNSs or social media has dynamic nature, which means the information about someone's personality is continuously available and can be tracked over time. Moreover, the novelty of this research's finding it will examine the young stock investor behavior through the Online Social Network Sites (SNS) usage by Instagram. Unfortunately, no known previous study considered analyzing the risk appetite risk by young investors' Instagram usage behavior in Indonesia.

In addition, Structural Equation Model PLS was used to analyze the young stock investor in university students behavior for their risk appetite and social media usage. We replicated from the previous research developed by Wehrli (2008); Wasiuzzaman and Edalat (2016). Furthermore, we modified later on by Sheldon (2015); Belanche, Flavian, and Ibanez-Sanchez (2020). We also extended this research to a new perspective for the young investor in university students when deciding to purchase the stock in Indonesia. We used the Indonesian language while distributed online questionnaires through Google form for our respondents.

This research will contribute in several ways. First, this result will enable the young stock investor to predict their risk appetite by evaluating their SNSs actions. Second, their investment manager can continuously update their services following the changing of young stock investor personality characteristics. Third, this research will update the financial behavior theories using technology for millennials stock investors through Instagram usage in Indonesia.

\section{Literature Review}

\section{Social Network Usage Behavior and Extroversion Personality}

According to Kujath (2011); Zhu and Bao (2018), social networking sites have become a favorite study subject in current years, all the more with the increasing importance of sites through the additional instruments for communication. Lenhart and Madden (2007); Bao (2016) stated the reasons behind social network usage, such as still getting connected with friends, keeping in touch with family and friends, and sharing information. Personality traits influence someone's decision to join SNSs such as Instagram, Facebook, and My Space.

Based on Buffardi and Campbell (2008) and Belanche et al. (2020), a frequent Instagram user with a lot of friends has a positive and significant correlation with narcissistic traits. Likewise, the more active participation in self-promotion in social networks is led by more narcissism and lower self-esteem (Mehdizadeh, 2010; Liu et al., 2019). Furthermore, in pursuance of Valenzuela et al. (2009) and Skues et al. (2012), Instagram's intensity is associated with social trust. Most likely, Instagram users put out their personal life information, although they know that strangers can find their information easily (Acquisti \& Gross, 2006; Fan et al., 2017). According to Walrave et al. (2012); Wiese and Akareem (2019), younger users have more trust in their social networks' friends. Thus they have a comfortable feeling for bringing out the individual information. Thus, in association with predicting personality are connecting to social media, for example, Instagram and Facebook (Wehrli, 2008; Ross et al., 2009; Amichai-Hamburger and Vinitzky, 2010).

According to McElroy et al. (2007), Devaraj et al. (2008), Guadagno et al. (2008), Wasiuzzaman and Edalat (2016), internet usage is related to the Big Five Personality factors instead of the cognitive style. At the same time, personality traits are connected to online action. Wehrli (2008) stated that the Big Five Personality factors consist of agreeableness, conscientiousness, extroversion, emotional stability, and openness to the new experience. Those studies found that the most accurate Big Five dimension is extroversion, which is predicted to align with face-to-face communications (Back et al., 2010). Amichai-Hamburger and Vinitzky (2010); Wasiuzzaman and Edalat (2016) also explained that extroverted personalities had an important role. It determines the Instagram usage patterns.

Extroversion personality showed in the talkative and social person. They are active and also an optimist. Wehrli (2008) declared that the more social interaction, people will become more extrovert. They connected with the other quickly and easily. Moreover, extroverts prefer face-to-face communication, so they are rarely found in online talking rooms (McElroy et al., 2007). Extrovert individuals usually spend more time on social networking media (Wilson et al., 2010; Lee, 2017). Additionally, extroverts are having more Instagram friends (Ong et al., 2010), logging on, and posting on Instagram more frequently ((Shoenberger \& Tandoc, 2014; Wasiuzzaman \& Edalat, 2016). It is due to the extroverts are enjoying their self-disclosure on social networks such as Instagram (Correa et al., 2010). Moreover, Amichai-Hamburger and Vinitzky (2010) stated that extroverts used social networking media for sharing their opinions and information. Yet, they did not want to share their personal matters because the real interaction could not be substituted.

\section{Extroversion Personality and Investment Risk Appetite}

The appetite for investment risk will show the risk tolerance when someone decides to invest in the stock market. It is one of the critical issues in finance. Different personalities led to different financial preferences. It is showed in their investment risk appetite for financial decisions. Since someone's risk attitude influences their choices in investment, it would help financial consultants predict their clients' characteristics through some data or information by Instagram usage behavior related to personality. The investment risk appetite is connected with sensation-seeking as well as the character of an extrovert (Harlow \& Brown, 1990). Specifically, someone who has an extrovert personality with a more sensation-seeking attitude led to a more aggressive investment risk appetite 
(Wasiuzzaman \& Edalat, 2016). Furthermore, the extrovert investor is also optimistic or even overestimate their investment return, so they can also have a higher investment risk appetite (Memarista, 2016)

Concerning risk-taking behavior, the users of social networking sites tend to be more risk-taker person instead of to the person who has not Instagram (Fogel \& Nehmad, 2009). Generally, the young risk-averse investor is being more silent observer about their colleague posts. The more risk-averse, they will more rarely post pictures and update their social media. Moreover, risk-taker investors also used social connection features in social networking sites more frequently (Shoenberger \& Tandoc, 2014). Risk-taker investors used Instagram for fulfilling their leisure time for escaping reality.

There is little research about SNSs activities along with stock investor risk tolerance in university students. So that, there is an excellent opportunity to figure out the investment risk appetite through SNSs action. Through this research, a financial consultant will be provided with more readily available information to assess the clients' personalities. The relationship among extroversion personality as well as the investment risk appetite have been researched, yet it is not about social networking sites contexture, for instance, the Instagram usage behavior.

\section{Hypothesis Development}

The users of social networking sites (SNSs), for example as Instagram, are from different backgrounds. Thus it makes Instagram users as good research targets. In this research, the variables used to measure different actions of Instagram users were considered to examine how Instagram usage behavior may relate to the investment risk appetite. After long consideration, variables, for instance, the amount of Instagram followers, investor's spending time on Instagram, the frequency of Instagram user to log on, Instagram usage for personal expression, as well as Instagram usage for social relation would use as the Instagram activities measurement. It was considered as the independent variable.

According to Wehrli (2008), Correa et al. (2010), Wasiuzzaman and Edalat (2016), social media site usage is positively related to the extroversion personality. An extrovert person has some characteristics. They are energetic and cheerful. Furthermore, extroverts were proven to be more sociable and also friendly. Thus, they are willing to spend more time getting more friends on Instagram compared to introvert users (Wilson et al., 2010).

Moreover, the capability of the internet, together with social networking sites (SNSs), will fulfill extrovert's need to have a higher degree of simulation and a more extensive social network. It may gain to over-obsession behavior towards the chance for reaching out to people and for exposing their information. Nevertheless, disagree with the expectation that risk-takers are active users in SNSs. The risk-takers might seek or view the online society when they are no longer novel and boring after several logs on Instagram to lead to inactive usage of SNSs.

A prior study related to extroversion personality has analyzed the relationship between narcissism personality and Instagram usage (Belanche et al., 2020). Narcissism is an extroversion personality trait that portrays a person who has the superfluous concept of themselves. They also have a higher level of importance of themselves and desire to be admired (Buffardi \& Campbell, 2008). Several prior studies found that narcissist individuals might be more inclined to get involved in those kinds of activities regarding selfpromoting and superficial behaviors, such as photo-sharing and updating status. A person with an extroverted personality will post their photos because they want to show their personal attractiveness (Kapidzic, 2013).

Moreover, extroversion was positively associated with the Instagram photo posting as well as how often they liked and gave comments on their colleague's Instagram feed (Sheldon, 2015). Furthermore, extrovert people are more likely to have more friends as followers, spend much more time on their SNSs, and check more frequently on their Instagram (Buffardi \& Campbell, 2008; La Sala et al., 2014). The extrovert tends to choose riskier investment strategies. It means that their investment assets decision is influenced by high-risk appetite levels (Foster et al., 2009). From those explanations from several prior studies, it can be concluded that an extrovert will more active on Instagram by examining his or her frequency of logging to the Instagram, the amount of Instagram follower, spending time on Instagram, and also prefer more aggressive to choose investment strategies (which indicated the higher level of investment risk appetite).

The connection among SNSs usage behavior through Instagram and extroversion personality, extroversion, and investment risk appetite can be interpreted as spending time on Instagram, the frequency of Instagram users to log on, and the number of followers on Instagram be associated with the extroversion personality. So, the first three hypotheses for this research are:

H1. Spending time on Instagram has a significant effect on extroversion personality

H2. The number of followers on Instagram has a significant effect on extroversion personality

H3. The frequency of logging on to Instagram has a significant effect on extroversion personality

The social compensation hypothesis declared that introverts who are socially worried also have problems in making networks. On the other hand, in real-life friendship, they are more likely to be the primary users of social networking sites (SNSs) to compensate for that weaknesses. Supporting this hypothesis, Kuss and Griffiths (2011) found that introverts will make use of social media for compensation. An introvert will share more about their personal information in the social media account. They also will update their Instagram status more. They will give comment more to the other Instagram user's posts too. Those indicate that using Social Networking Sites (SNSs) by individuals is more often for communication purposes with their colleagues. It showed that it happened without a real-life need for intimacy and proximity.

Nevertheless, according to Harlow and Brown (1990), introverts are non-sensation-seeking persons who feel discomfort with investment risk. So, it can be concluded that a risk-averse person is an introvert. They used Instagram to compensate for their real-life relationship, which they are really missing out. So that, they used it for self-expression and got social relations. Contrary to the statement before, Shoenberger and Tandoc (2014) stated that risk-takers tend to use social networks to fulfill excitement and escape reality. Instagram has some self-expression features which people can use to provide several methods for seeking excitement. Yet, the risk-averse people's goal of using Instagram is for connecting with family, friends, and acquaintances that they met offline, not for selfexpression purposes. Based on those statements, the fourth and fifth hypotheses are as follows:

H4. The use of Instagram for personal expression has a significant effect on extroversion personality. 
H5. The use of Instagram for social relations has a significant effect on extroversion personality.

Moreover, related to risk tolerance, the extroversion personality is expected to be positively associated with the investment risk appetite. Hence, the sixth hypothesis for this research is as follows:

H6. The extroversion personality has a significant effect on investment risk appetite.

\section{Materials \& Methods}

\section{Sampling and Questionnaire Design}

To test the hypotheses above, online questionnaires were distributed to the young stock investors, which are undergraduate students in Indonesia. In this research, homogeneous purposive sampling is chosen as the sampling method. The online questionnaires were distributed by using the Google Form questionnaire. The number of online questionnaires was collected, 325 responses. Because of the incomplete data along with respondent's duplication responses, the researchers exercised only 300, which were useable for further step analysis.

The questionnaire consisted of three parts. The first part focuses on the investors' Instagram activities that show the SNSs usage behavior through Instagram. Respondents were asked to state the number of followers on Instagram (FOL), spending time on Instagram (TS), which shows the total amount of time in minutes which each investor spends on Instagram in a day, and the frequency of Instagram user to log on in the Instagram (FLOG) that showed the frequency logging on without entering their username account and password for a full day. A five-point Likert scale is used for responses on frequency also a score of 1 to 5 is given to items as follows: $1=$ never, $2=$ very rarely, $3=$ rarely, $4=$ often, and $5=$ always. To analyze the use of Instagram for personal expression, three statements are provided that investors have to rate using a five-point Likert scale, the same with the score for frequency. The items asked the investors to show the expression of themself about how frequently they upload pictures (SE1), update their status via an Instagram story (SE2), and express themselves on Instagram via comments (SE3). Next, for measuring Instagram usage for social relations, two statements are provided. Investors have to rate using a five-point Likert scale, the same as for the frequency and self-expression items. The two items asked investors how frequently they posted comments (SC1) and viewed another Instagram user's profile on Instagram (SC2).

Part two of the questionnaire consists of investment risk appetite (IRA) questions from Grable and Lytton (1999). It measured three concepts of financial risks, such as investment risk (IRA1), convenience and experience risk (IRA2), and speculative risk (IRA3). IRA will represent and demonstrate the level of risk tolerance for young individual stock investors in terms of financial preference and their attitude based on their investment risk.

The third or last part of the questionnaire for extroversion personality (EXT) consists of 5 statements representing the Big Five Model. It is picked up from Robbins et al. (2016). The extroversion score of each investor is obtained by averaging the score from each statement. The score of each statement is using a five-point Likert scale. The scale is as follows: 1 = totally disagree, 2 = disagree, 3 = neutral, 4 = agree, $5=$ totally agree. A person can have an extroversion personality when his or her extroversion score is 3.0 and above.

\section{Results and Discussion}

Data examinations used in this research are as follows: discriminant validity, convergent validity, composite reliability, and average variance extracted (AVE). These examinations were expected to show the data validity and reliability from the questionnaire which is used in this study. Data analysis is using SMART PLS version 3.0. 


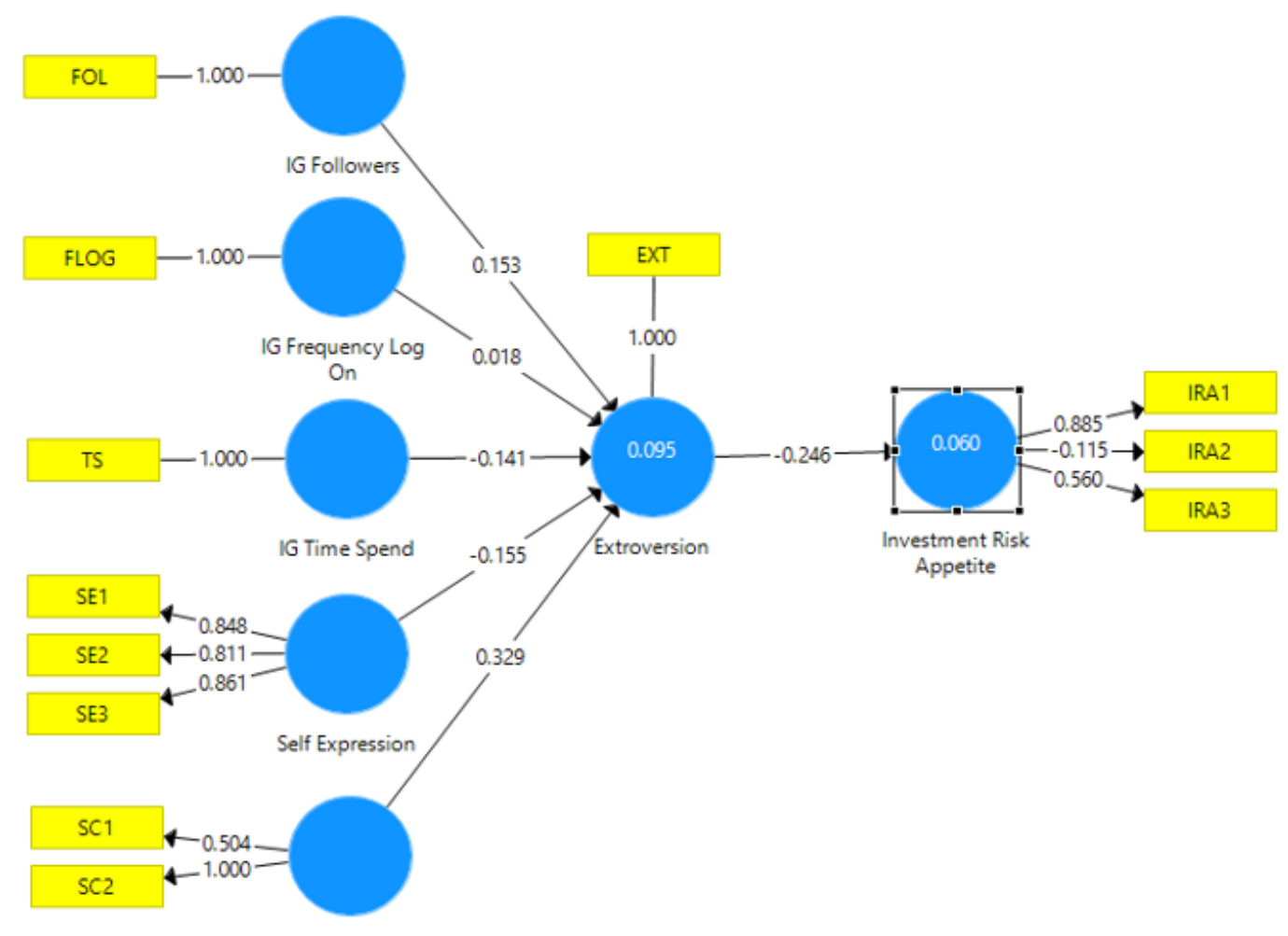

Figure 1. The Estimate Model of Young Investor's Instagram Usage Behavior on Investment Risk Appetite

According to Sekaran and Bougie (2010) and Hair et al. (2010), the data in this questionnaire will be tested with several measurements of Goodness of Fit $(\mathrm{GoF})$. The first measurement is the convergent validity test through seeing the loading factors value. The loadings for every item have to be valid in the score of 0,5 . If the indicator outer loading value is lower than 0,5, it must be excluded from the model. The second measurement is the Discriminant Validity test using cross-loadings value. According to the Discriminant Validity test, the term of valid block indicator must have a higher value of measuring its construct variable than another construct variable in the research. The third measurement is seeing the Average Variance Extracted (AVE). This test aims to evaluate whether the Convergent and Discriminant Validity is good or not. If the AVE value of each indicator is more than 0.5 , it can be concluded that the Convergent and Discriminant Validity test is good. The last measurement is checking the indicators' reliability using Composite Reliability value. If the Composite Reliability value of each indicator is more than 0.6 , it can be stated that the indicators which used in the research are reliable.

According to that set of Goodness of Fit examination, the indicator is not valid, i.e., AIR2. Due to this condition, one indicator is excluded from the research. Hence, the research construct is changed (see Figure 2). 


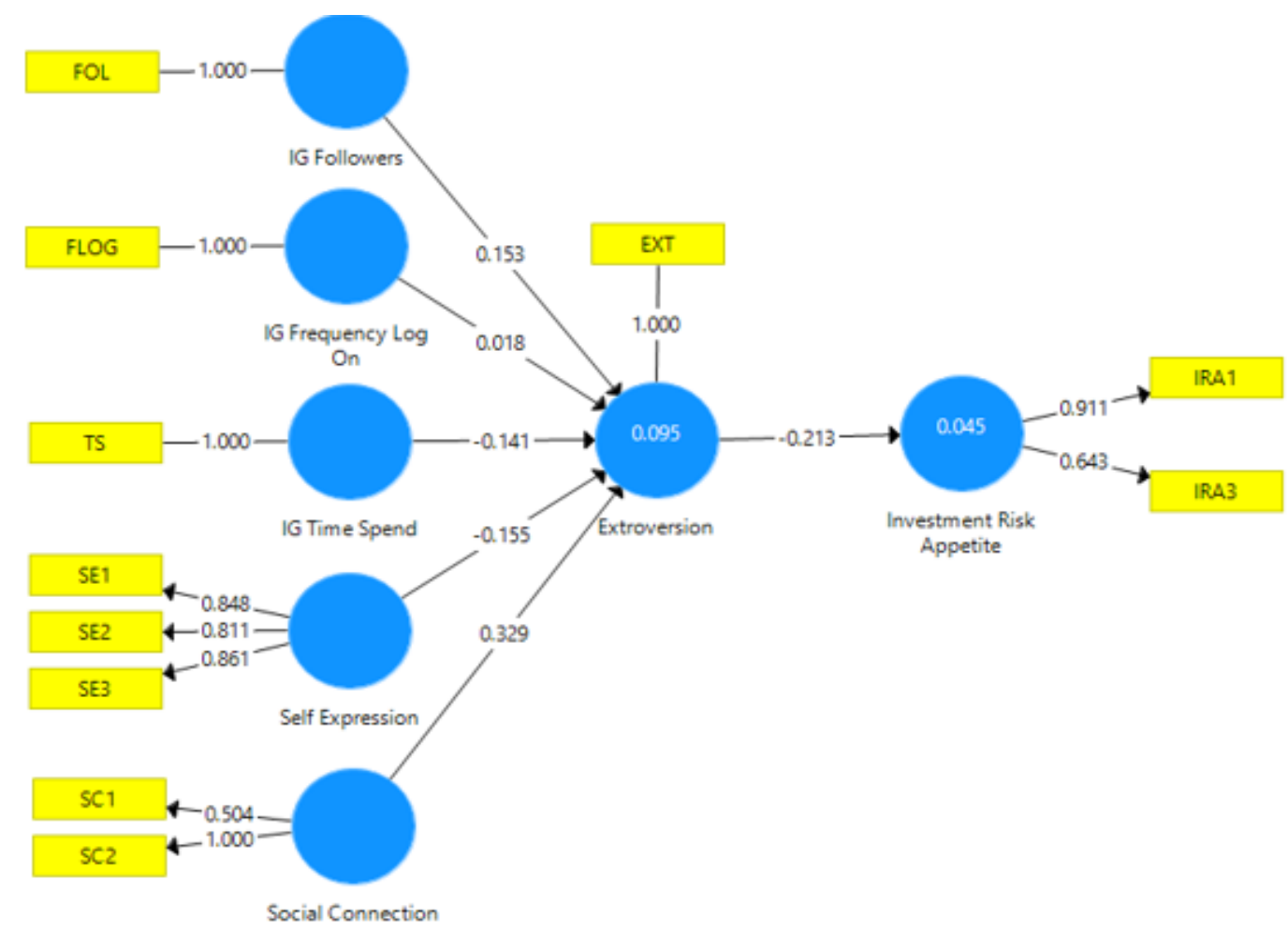

Figure 2. PLS Research Model After Invalid Indicators Is Reduced

After the reduction, the goodness of fit measurement can be restarted. The first measurement is the Convergent Validity through evaluating the loading factors value of each indicator after removal. Finally, the value of the loading factor for each indicator is more than 0.5. Hence, all the indicators are valid and can be used for the research (see Table 1).

Table 1. Convergent Validity Test Results

\begin{tabular}{|c|c|c|c|c|}
\hline Dimension & & Items & Factor Loadings & Adapted From \\
\hline \multirow[t]{2}{*}{ Investment Risk Appetite } & IRA1 & Investment Risk Concept & 0,911 & Grable \& Lytton (1999) \\
\hline & IRA3 & Speculative Risk Concept & 0,643 & Foster et al. (2009) \\
\hline Extroversion & EXT & $\begin{array}{l}\text { Statement of Having } \\
\text { Extroversion Personality }\end{array}$ & 1,000 & $\begin{array}{l}\text { Wehrli (2008); Correa et al. (2010); } \\
\text { Robbins et al. (2016); }\end{array}$ \\
\hline IG Followers & FOL & $\begin{array}{l}\text { The Number of IG } \\
\text { Followers }\end{array}$ & 1,000 & Ryan \& Xenos (2011) \\
\hline IG Frequency Log On & FLOG & $\begin{array}{c}\text { The Frequency of Logging } \\
\text { on to IG }\end{array}$ & 1,0000 & $\begin{array}{c}\text { Ryan \& Xenos (2011); } \\
\text { Wasiuzzaman \& Edalat (2016) }\end{array}$ \\
\hline IG Time Spend & TS & Spending Time on IG & 1,000 & Ong et al. (2010) \\
\hline \multirow[t]{3}{*}{ Personal Expression } & SE1 & Frequency Upload Pictures & 0,848 & Kuss \& Griffiths (2011) \\
\hline & SE2 & $\begin{array}{c}\text { Frequency Update Status } \\
\text { via IG story }\end{array}$ & 0,811 & Wasiuzzaman \& Edalat (2016) \\
\hline & SE3 & $\begin{array}{l}\text { Express on IG via } \\
\text { Comments }\end{array}$ & 0,861 & Kapidzic, (2013); Sheldon, 2015). \\
\hline \multirow[t]{2}{*}{ Social Relation } & SC1 & $\begin{array}{l}\text { Frequency Write } \\
\text { Comments on IG }\end{array}$ & 0,504 & $\begin{array}{c}\text { Kuss \& Griffiths (2011); } \\
\text { Shoenberger \& Tandoc (2014) }\end{array}$ \\
\hline & SC2 & $\begin{array}{l}\text { View Someone Else's } \\
\text { Profile on IG }\end{array}$ & 1,000 & Harlow \& Brown (1990) \\
\hline
\end{tabular}

The next test is the Discriminant Validity using cross-loadings value. The cross-loading value of each block indicator is valid because the constructed variable is higher than their indicator for each to measure the other construct variable in the research (see Table 2).

Table 2. The Discriminant Validity Test Results

\begin{tabular}{ccccccccc}
\hline Dimension & Items & $\begin{array}{c}\text { Appetite of } \\
\text { Investment } \\
\text { Risk }\end{array}$ & Extroversion & $\begin{array}{c}\text { IG } \\
\text { Followers }\end{array}$ & $\begin{array}{c}\text { IG } \\
\text { Frequency } \\
\text { Log on }\end{array}$ & $\begin{array}{c}\text { IG } \\
\text { Time } \\
\text { Spend }\end{array}$ & $\begin{array}{c}\text { Self } \\
\text { Expression }\end{array}$ & $\begin{array}{c}\text { Social } \\
\text { Connection }\end{array}$ \\
\hline $\begin{array}{c}\text { Investment Risk } \\
\text { Appetite }\end{array}$ & IRA1 & 0,911 & $-0,207$ & $-0,156$ & $-0,016$ & $-0,148$ & $-0,120$ & $-0,101$ \\
\end{tabular}




\begin{tabular}{|c|c|c|c|c|c|c|c|c|}
\hline & IRA3 & 0,643 & $-0,112$ & 0,076 & 0,023 & 0,091 & 0,093 & 0,040 \\
\hline Extroversion & $\mathrm{EXT}$ & $-0,213$ & 1,000 & 0,127 & 0,089 & $-0,054$ & 0,089 & 0,244 \\
\hline IG Followers & FOL & $-0,091$ & 0,127 & 1,000 & 0,112 & 0,220 & 0,416 & 0,206 \\
\hline $\begin{array}{l}\text { IG Frequency } \\
\text { Log On }\end{array}$ & FLOG & $-0,003$ & 0,089 & 0,112 & 1,000 & 0,257 & 0,389 & 0,457 \\
\hline IG Time Spend & TS & $-0,079$ & $-0,054$ & 0,220 & 0,257 & 1,000 & 0,173 & 0,229 \\
\hline Personal & SE1 & $-0,081$ & 0,070 & 0,426 & 0,284 & 0,222 & 0,848 & 0,479 \\
\hline \multirow{4}{*}{ Social Relation } & SE2 & $-0,010$ & 0,059 & 0,387 & 0,351 & 0,211 & 0,811 & 0,612 \\
\hline & SE3 & $-0,044$ & 0,089 & 0,268 & 0,347 & 0,044 & 0,861 & 0,456 \\
\hline & SC1 & 0,023 & 0,008 & 0,289 & 0,156 & 0,145 & 0,520 & 0,704 \\
\hline & SC2 & $-0,065$ & 0,247 & 0,200 & 0,459 & 0,228 & 0,586 & 1,000 \\
\hline
\end{tabular}

The third examination that should be done is seeing the Average Variance Extracted (AVE) value, also as the Discriminant Validity. After some checking, it concludes that the Convergent and Discriminant Validity in this research is good because the AVE value of each variable is more than 0.5 . Fourth is the Composite Reliability and Cronbach Alpha. The questionnaire data is reliable because the Composite Reliability value of each indicator is more than 0.6 . Hence, it indicates that all the Goodness of Fit measurement results for this research is very satisfying.

Table 3. Average Variance Extracted (AVE) and Reliability Test Results

\begin{tabular}{cccc}
\hline Indicators & Average Variance Extracted (AVE) & Composite Reliability & Cronbach Alpha \\
\hline Investment Risk Appetite & 0,621 & 0,761 & 1,000 \\
Extroversion & 1.000 & 1,000 & 1,000 \\
IG Followers & 1.000 & 1,000 & 1,000 \\
IG Frequency Log On & 1.000 & 1,000 & 1,000 \\
IG Time Spend & 1.000 & 1,000 & 0,624 \\
Personal Expression & 0,706 & 0,878 & 0,796 \\
Social Relation & 0,627 & 0,752 & 0,649 \\
\hline
\end{tabular}

Table 4 presents the descriptive statistic of this study about demography data and all variables for this research. The study consists of 300 observations. It indicates that the sample was dominated by male investors (55\%) and age 20 (28\%).

Table 4. Descriptive Statistics

\begin{tabular}{|c|c|c|c|c|}
\hline Demographic Data & \multicolumn{2}{|c|}{ Category } & Frequency & Percentage (\%) \\
\hline \multirow[t]{2}{*}{ Gender } & \multicolumn{2}{|c|}{ Male } & 165 & 55 \\
\hline & \multicolumn{2}{|c|}{ Female } & 135 & 45 \\
\hline \multirow[t]{7}{*}{ Age } & \multicolumn{2}{|c|}{17} & 3 & 1 \\
\hline & \multicolumn{2}{|c|}{18} & 42 & 14 \\
\hline & \multicolumn{2}{|c|}{19} & 78 & 26 \\
\hline & \multicolumn{2}{|c|}{20} & 84 & 28 \\
\hline & \multicolumn{2}{|c|}{21} & 63 & 21 \\
\hline & \multicolumn{2}{|c|}{22} & 27 & 9 \\
\hline & \multicolumn{2}{|c|}{23} & 3 & 1 \\
\hline Variables & Items & Mean & Min & Max \\
\hline \multirow[t]{2}{*}{ Investment Risk Appetite } & IRA1 & 10,566 & 6 & 16 \\
\hline & IRA3 & 5,202 & 3 & 8 \\
\hline Extroversion & EXT & 0,737 & 0 & 1 \\
\hline IG Followers (persons) & FOL & 791,152 & 44 & 4.472 \\
\hline IG Frequency Log On & FLOG & 4,172 & 1 & 5 \\
\hline IG Time Spend (minutes) & TS & 185,778 & 2 & 1.080 \\
\hline \multirow[t]{3}{*}{ Personal Expression } & SE1 & 2,646 & & \\
\hline & SE2 & 2,869 & & \\
\hline & SE3 & 2,687 & & \\
\hline \multirow[t]{2}{*}{ Social Relation } & SC1 & 2,515 & & \\
\hline & SC2 & 3,465 & & \\
\hline
\end{tabular}

The variables in this research study are investment risk appetite and extroversion personality as the dependent variables. Next, the number of followers on Instagram, spending time on Instagram, frequency of log on to Instagram, the use of Instagram for personal expression, and the use of Instagram for social relations as the independent variables. Table 4 implies that the young stock investors in this research have low the use of Instagram for personal expression and the use of Instagram for social relation. The mean values for those two variables are lower than the midpoint in the five Likert Scale, which are 2,734 and 2,990 for the use of Instagram for personal expression and the use of Instagram for social relation.

Table 5 shows these research results. The results table shows that the number of followers on Instagram and the use of Instagram for social relations significantly affect the extroversion personality at $p$-values of $5 \%$ and $10 \%$. Otherwise, spending time on 
Instagram, frequency of log on to Instagram, and the use of Instagram for personal expression did not significantly affect the extroverted personality. Furthermore, R-square and Adjusted R-square value is 9,5\% and 4,7\%, which means there are independent variables out there that can explain more about the extroversion personality.

Additionally, Table 5 also shows that extroversion personality significantly affects the investment risk appetite at a p-value of $10 \%$. R-square and Adjusted R-square value is 4,5\% and 3,5\% related to how significant the influence is. Moreover, the Structural Equation Model, which can be seen through the Q-square value, is 0,3\%. From this result, it can be concluded that the independent variables which have been used in this research are not good enough to predict the investment risk appetite through the extroversion personality as the moderating variable.

Table 5. Structural Equation Model Results

\begin{tabular}{cccc}
\hline Dependent Variable: & Extroversion Personality & & \\
\hline Independent Variables & Coefficient & T-Stats & P-Values \\
\hline IG Followers & 0,153 & 1,969 & $0,049^{* *}$ \\
IG Frequency Log On & 0,018 & 0,154 & 0,878 \\
IG Time Spend & $-0,141$ & 1,152 & 0,250 \\
Personal Expression & $-0,155$ & 0,995 & 0,320 \\
Social Relation & 0,329 & 1,755 & $0,080^{*}$ \\
R-Square & 0,095 & & P-Values \\
R-Square Adjusted & 0,047 & $0,051^{*}$ \\
Dependent Variable: & Investment Risk Appetite & T-Stats \\
\hline Independent Variables & Coefficient & 1,960 & \\
Extroversion & $-0,213$ & & \\
R-Square & 0,045 & & \\
R-Square Adjusted & 0,035 & & \\
Q-Square & 0,003 & &
\end{tabular}

Note: ${ }^{*}$ and ${ }^{* *}$ refer to p-value statistic level at $10 \%$ and $5 \%$

First, this research results show that the number of Instagram followers as the SNSs usage behavior significantly affected the extroverted personality. The most reasonable reason for this study result is because they have known the followers of investors' Instagram account in his research. They are investor's friends for the owner of the Instagram account. Moreover, mostly the followers are really familiar and know who the owner of the Instagram account they follow. Because they do not just randomly follow other people's Instagram account, so thus they will interact online, be open to their peers, and share financial information (Ryan \& Xenos, 2011; Wasiuzzaman \& Edalat, 2016). Hence, this variable can be the proper factor to predict the extroversion personality with regard to the reason.

Second, the variable that is not significantly affected the extroverted personality is the frequency of log on to the Instagram account. The most reasonable reason for this is because, nowadays, young people in Indonesia tend to check their SNSs account, including Instagram, frequently (Ryan \& Xenos, 2011). It can even be due to logging on to Instagram without entering the username and password. It has already been set on their mobile phone or their gadget. Even the respondents in this research often intend to see what their friends, family, and acquaintances are sharing in the Instagram at the moment, which triggered them to always log on to their Instagram, regardless of what their personality is. Hence, it can be concluded that this variable is not proper to use if the research area is in Indonesia.

Third, the variable that shows SNSs usage behavior that is found not significantly affected the extroversion personality is time spent on Instagram. Nowadays, either the investors are extroverts or introverts, the respondents can spend as much time as they want as much as they like if there is free time (Ong et al., 2010). This is because SNSs, including Instagram usage behavior, provide various financial information which some people want to know simply every time the respondents need. Instagram ownership can prove it by capital market authority firm and security companies to provide financial information to their stock investors, especially young investors.

Fourth, the use of Instagram for self-expression has not significant impact towards the extroverted personality. Hence, it can be stated that more frequently, someone uses Instagram to express themselves through some kind of online activities such as posting photos, updating status through Instagram story, and posting comments. They tend not to be extreme extroverts or narcissists only (Kuss \& Griffiths, 2011). It is also because they have much time to do online activities to looking for information via Instagram and not just posting photos, updating status, or posting comments (Kapidzic, 2013; Sheldon, 2015). In fact, our respondents in this research often tend to view Instagram feeds, Instagram stories, Instagram Live TV, and read their captions from their followers or the Instagram that they followed. Thus, the respondents in this study have lower self-expression to use Instagram.

Fifth, this research results also proving that the use of Instagram for social relations has a positive and significant impact towards the extroverted personality. It can be explained that the young person is looking for a networking connection at their young age by staying connected with their long friends, family, and acquaintances. Because of that, they tend to be an extrovert or even a narcissist to still correspond with their colleagues. Also, it is consistent with the research result that written by Wasiuzzaman and Edalat (2016) that stated young persons are using Instagram, generally to improve their social relations. The respondents in this study tend to use Instagram for connections to look for financial information by following Instagram account from financial companies such as bank and non-bank. In addition, the respondent, which is young stock investors, indeed follow every Instagram account which provides financial information or financial knowledge. So that it indicates the respondent in this study has an Instagram account to 
establish the connection and get information to increase investors' financial knowledge.

Sixth, this research results also show that the extroversion personality has a negative and significant impact towards the investment risk appetite. It can be stated that the higher the extroversion level, the investment risk appetite is getting lower. It happened because the extrovert is very open with all sources of investment information. It is consistent with Harlow and Brown (1990) and Foster et al. (2009), who stated that someone with an extrovert personality and higher degrees of sensation-seeking attitude. When the extrovert knows a lot, they become afraid about the investment risk that will be borne and can cause losses. So that, even someone with an extroversion personality stated a narcissist person, they can have a lower investment risk appetite. Incredibly, this study asked the respondents to fulfill the questionnaires in 2020 which an economic crisis occurred due to the coronavirus pandemic. It caused the capital market and stock investment to decline. Thus, even if they are extroverts, the respondents would seek to get a lot of investment information through Instagram. Yet, this incident caused them to be afraid of stock investment risks and become young stock investors who really consider risks to minimize losses.

\section{Conclusions}

Social networking sites (SNSs) by Instagram are among many places that provide a considerable amount of information that should be explored, especially for developing the finance field. This research aims to examine the possible impact of various SNSs activities such as Instagram usage behavior towards the investment risk appetite through the extroversion personality.

This research shows that several individual investors' Instagram usage behavior can predict his/her tendency to be an extrovert or introvert, which can explain their risk appetite level. The results study show that the number of followers on Instagram and the use of Instagram for social connection significantly affect the extroverted personality. The extroversion personality significantly affects the investment risk appetite. Otherwise, spending time on Instagram, frequency of log on to Instagram, the use of Instagram for self-expression do not considerably affect the extroverted personality.

This research will add knowledge related to investment risk appetite and social networking sites (SNSs), especially Instagram usage behavior. Predicting the investment risk appetite by evaluating SNSs usage behavior is possible to provide financial consultants with additional dynamic data sources. So that they can in line with their clients and serve them in the best way of financial service. This research also contributes to expanding the theories related to extroversion personality and investment risk appetite.

This research has many limitations which need to be repaired in the future. First, the sampling method for this research is homogeneous purposive sampling. The respondents are young stock investors in university students, so the results may not represent the general population in Indonesia. Maybe, in the future, the researcher can add financial experts or investment professionals as the sample to improve the overall result of the research. Second, this study only used extroversion from the Big Five personality model. For the following associate research, all of the Big Five personalities can be used in the study to see the possible impact of each personality trait towards the investment risk tolerance. Last, the R-square values and Q-square value are too small, which means more variables can predict, both extroversion and investment risk appetite better. So, for the future, associate research can be added with some factors which proved in influencing extroversion personality and investment risk appetite.

\section{References}

Acquisti, A., \& Gross, R. (2006). Imagined communities: Awareness, information sharing, and privacy on Facebook. Privacy Enhancing Technologies, 4258, 36-48.

Amichai-Hamburger, Y., \& Vinitzky, G. (2010). Social network use and personality. Computers in Human Behavior, 12891295.

Back, M. D., Stopfer, J. M., Vazire, S., Gaddis, S., Schmukle, S. C., Egloff, B., \& Gosling, S. D. (2010). Facebook profiles reflect actual personality, not self-idealization. Psychological Science: A Journal of the American Psychologist Society/APS, 21(3), 372-374.

Bao, Z. (2016). Exploring continuance intention of social networking sites: An empirical study integrating social support and network externalities. Aslib Journal of Information Management, 68(6), 736-755.

Belanche, D., Flavian, M., \& Ibanez-Sanchez, S. (2020). Followers' reaction to influencers' Instagram posts. Spanish Journal of Marketing. 24(1), 37-53.

Buffardi, L. E., \& Campbell, W. K. (2008). Narcissism and social networking websites. Personality and Social Psychology in Bulletin, 34(10), 1303-1314.

Brahmana, R., \& Memarista, G. (2017). Financial planning behavior among the young: Evidence from Malaysian University Students. Global \& Local Economic Review. 21(2),29-54.

Correa, T., Hinsley, A., \& de Zúñiga, H. (2010). Who Interacts on the web?: The intersection of users' personality and social media use. Computers in Human Behavior, 26(2), 247-253.

Devaraj, S., Easley, R. F., \& Crant, J. M. (2008). Research note - how does personality matter? Relating the five-factor model to technology acceptance and use. Information Systems Research, 19(1), 93-105.

Fan, A., Shen, H., Wu., L., Mattila, A., \& Bilgihan, A. (2017). Whom do we trust? Cultural difference in consumer responses to online recommendations. International Journal of Contemporary Hospitality Management, 30(3), 15081525.

Filbeck, G., Hatfield, P., \& Horvath, P. (2005). Risk aversion and personality type. Journal of Behavioral Finance, 6(4), 170180. 
Fogel, J., \& Nehmad, E. (2009). Internet social network communities: Risk-taking, trust, and privacy concerns. Computers in Human Behavior, 25(1), 153-160.

Foster, J., Misra, T., \& Reidy, D. (2009). Narcissists are approach-oriented toward their money and their friends. Journal of Research in Personality, 43(5), 764-769.

Guadagno, R., Okdie, B., \& Eno, C. (2008). Who blogs? Personality predictors of blogging. Computers in Human Behavior, 24(5), 1993-2005.

Grable, J., \& Lytton, R. H. (1999). Financial risk tolerance revisited: The development of a risk assessment instrument. Financial Services Review, 8, 163-181.

Hair, J. F., Black, W. C., Babin, B. J., \& Anderson, R. E. (2010) Multivariate data analysis. 7th edition. Upper Saddle River, NY: Prentice-Hall.

Harlow, W. V., \& Brown, K. C. (1990). Understanding and assessing financial risk tolerance: A biological perspective. Financial Analysts Journal, 46(6), 50-62.

Kapidzic, S. (2013). Narcissism as a predictor of motivations behind Facebook profile picture selection. Cyberpsychology, Behavior, and Social Networking, 16, 14-19.

Kemp, S. (2020). Digital 2020: Indonesia. Retrieved 23 March 2020 from https:/ / datareportal.com/reports/digital-2020indonesia\#: :text=There\%20were $\% 20160.0 \% 20$ million\%20social,at\%2059\%25\%20in\%20January\%202020.

Kujath, C. L. (2011). Facebook and myspace: Complement or substitute for face-to-face interaction? Cyberpsychology, Behavior and Social Networking, 14(1-2), 75-78.

McElroy, J., Hendrickson, A., Townsend, A., \& DeMarie, S. (2007). Dispositional factors in internet use: Personality versus cognitive style. MIS Quarterly, 31(4), 809-820.

Mehdizadeh, S. (2010). Self-presentation 2.0: Narcissism and self-esteem on Facebook. Cyberpsychology, Behavior and Social Networking, 13(4), 357-364.

Kuss, D. J., \& Griffiths, M. D. (2011). Online social networking and addiction - a review of the psychological literature. International Journal of Environmental Research and Public Health, 8(9), 3528-3552.

La Sala, L., Skues, J., \& Grant, S. (2014). Personality traits and Facebook use the combined/interactive effect of extraversion, neuroticism, and conscientiousness. Social Networking, 3(5), 211-219.

Lee, I. (2017). A study of the effect of social shopping deals on online reviews. Industrial Management $\mathcal{E}$ Data Systems. 117(10), 2227-2240.

Lenhart, A., \& Madden, M. (2007). Social networking websites and teens: An overview. Retrieved May 8, 2020, from Pew Internet and American Life Project, Pew Research Centre: www.pewinternet.org/files/oldmedia//Files/Reports/2007/PIP_SNS_Data_Memo_Jan_2007.pdf.pdfLiu, Q., Shao, Z., Tang, J., \& Fan, W. Examining the influential factors for continued social media use. Industrial Management $\mathcal{E}$ Data Systems, 119(5), 1104-1127.

Liu, Q., Shao, Z., Tang, J., \& Fan, W. (2019). Examining the influential factors for continuing social media use: A comparison of social networking and microblogging. Industrial Management \& Data Systems, 119(5), 1104-1127.

Memarista, G. (2016). Managerial optimism and debt financing: Case study on Indonesia's manufacturing listed firms. Jurnal Keuangan dan Perbankan, 20(3), 438-447.

Ong, E., Ang, R., Ho, J., Lim, J., Goh, D., \& Lee, C. (2010). Narcissism, extraversion, and adolescents' self-presentation on Facebook. Personality and Individual Differences, 50(2), 180-185.

Robbins, S. P., Judge, T., Millett, B., \& Boyle, M. (2016). Organizational behavior. $8^{\text {th }}$ edition, Melbourne: Person Australia Group Pty Ltd.

Ross, C., Orr, E. S., Sisic, M., Arseneault, J. M., Simmering, M. G., \& Orr, R. R. (2009). Personality and motivations associated with Facebook use. Computers in Human Behavior, 25(2), 578-586.

Ryan, T., \& Xenos, S. (2011). Who uses Facebook? An investigation into the relationship between the Big Five, shyness, narcissism, loneliness, and Facebook usage. Computers in Human Behavior, 27(5), 1658-1664.

Sekaran, U., \& Bougie, R. (2010). Research methods for business: A skill-building approach. $5^{\text {th }}$ edition. UK: John Wiley \& Sons Ltd.

Sheldon, P. (2015). Self-monitoring and narcissism as predictors of sharing Facebook photographs. Tampa: Southern States Communication Association Conference.

Shoenberger, H., \& Tandoc, E. (2014). Updated statuses: understanding Facebook uses through explicit and implicit measures of attitudes and motivations. Online Journal of Communication and Media Technologies, 4(1), 217-244.

Skues, J. L., Williams, B., \& Wise, L. (2012). The effects of personality traits, self-esteem, loneliness, and narcissism on Facebook use among university students. Computers in Human Behavior, 28(6), 2414-2419.

Valenzuela, S., Park, N., \& Kee, K. F. (2009). Is there social capital in a social network site? Facebook use, and college students' life satisfaction, trust, and participation. Journal of Computer-Mediated Communication, 14(4), 875-901.

Walrave, M., Vanwesenbeeck, I., \& Heirman, W. (2012). Connecting and protecting? Comparing predictors of selfdisclosure and privacy settings use between adolescents and adults. Cyberpsychology: Journal of Psychosocial Research on Cyberspace, 6(1), Article 3.

Wasiuzzaman, S., \& Edalat, S. (2016). Personality, risk tolerance, and social network use: An exploratory study. Managerial Finance, 42(6), 536-552.

Wehrli, S. (2008). Personality on social network sites: An application of the five-factor model. Working Paper No. 7. Zurich.

Wiese, M., \& Akareem, H., S. Friends with benefits: Can firms benefit from consumer's sense of community in brand Facebook pages?. European Business Review, 31(6), 947-969. 
Wilson, K., Fornasier, S., \& White, K. M. (2010). Psychological predictors of young adults' use of social networking sites. Cyberpsychology, Behavior and Social Networking, 13(2), 173-177.

Zhu, Y., \& Bao, Z. (2018). The role of negative network externalities in SNS fatigue: An empirical study based on impression management concern, privacy concern, and social overload. Data Technologies and Applications, 52(3), 313-328. 